\title{
Re-evaluation of Discovered Devonian Hydrocarbon Pools in Concession NC8A, Ghadames (Hamada) Basin, NW Libya: Volumetric Techniques Based on Deterministic Method
}

\author{
Omar B. Elfigih* \\ Associate Professor, Petroleum Geologist, Department of Earth Sciences, \\ Faculty of Science, University of Benghazi, Benghazi-Libya
}

*Corresponding Author: Omar B. Elfigih, Associate Professor, Petroleum Geologist, Department of Earth Sciences, Faculty of Science, University of Benghazi, Benghazi-Libya, Email: omar.elfigih@uob.edu.ly

\begin{abstract}
The Lower, Middle and Upper Devonian hydrocarbon pools in the Concession NC8A of the Ghadames (Hamada) Basin, NW Libya were re-evaluated by using volumetric estimation based on deterministic method. This applied method has revealed that, the total oil in place "from all Devonian sandstone pools in Concession NC8A" is 36.12MMSTB. This represents $53 \%$ of the oil contributed from ElHamra Field ( $F, I$ AA and V structures), while a least percentage of only $4.5 \%$ is contributed from Emgayet Field (FFF and FF structures). Other Fields; "GG", "LL", " $Y$ ", "O" and "A" are contributed 0.8\%, 5.5\%, $9 \%, 10 \%$ and $20.5 \%$ respectively. In the other hand. a total gas in place "from all Devonian sandstone pools in Concession NC8A" is 5.21 BSCF and was estimated to reveal various percentages; 54\% is contributed from LL-Field, 30\% from F-structure of ElHamra Field, 6\% from FFF-structure of Emgayet Field and 3\% is contributed from A-Field. The remaining recoverable oil and gas are 14.25 million barrels of oil and 4.12 billion cubic feet of natural gas, $39.5 \%$ and $79 \%$ respectively of the total Concession NC8A.

In this study the uncertainty in the hydrocarbon estimation can be reduced to a certain extent if additional geological interpretation and 3D modelling of the studied pools are included in the estimation procedures and, consequently, the reliability of the estimates is enhanced. To achieve maximum effectiveness, oil and gas estimation by deterministic method should possess these types of flexibility.
\end{abstract}

Keywords: Re-evaluation, Hydrocarbon Pools, Devonian, volumetric estimation, deterministic method, Ghadames Basin.

\section{INTRODUCTION}

The Concession NC8A (ElHamra-Emgayet Fields vicinity) is located in southern central part of the Ghadames (Hamada) Basin, some $400 \mathrm{~km}$ south of Tripoli. It is bounded by the latitudes $28^{\circ} 55^{\prime \prime}$ and $29^{\circ} 35^{\prime \prime}$ and the longitudes $12^{\circ} 30^{\prime \prime}$ and $13^{\circ} 33^{\prime \prime}$ (Fig.1). Exploration activities in the Concession NC8A (old concession 66) had started in the end of 1959 beginning of the $1960^{\mathrm{s}}$ by the Gulf Oil Company when they attempted to drill the oil well A1-66 on a relevant structure. Other structures namely (AA, F, I, O, and V structures) were also discovered within the period between 1960-1970. The exploration activities were carried over by the National Oil Corporation of Libya (NOC) (19701978) to record a good success on the ElHamra and Emagyet Fields. Arabian Gulf Oil Compnay (AGOCO) was handling exploration activities in this concession since $1980^{\mathrm{s}}$ till now, and they drilled exploratory and development wells in the vicinity of ElHamra and Emgayet Fields to the north and the LL-Field to the south [1]. It occupies an area of about $3500 \mathrm{~km}^{2}$. To date a total of about 100 wells have been drilled in this concession, at least half of them are on production. Seven (7) oil and gas fields were defined in which 11 producing oil/gas pools were identified which occurred mainly in the Lower Devonian Ouankasa Formation, Middle Devonian Aouinat Ouenine "A" Member and Upper Devonian Tahara Formation. (Fig.2).

The main objectives of this study were 1) to define possible Devonian hydrocarbon pools in Concession NC8A and 2) to re-evaluate these pools on the basis of available production tests, testing reports and detailed stratigraphic and structures maps to better estimate the total hydrocarbon reserves in the Concession NC8A. 
Re-evaluation of Discovered Devonian Hydrocarbon Pools in Concession NC8A, Ghadames (Hamada) Basin, NW Libya: Volumetric Techniques Based on Deterministic Method

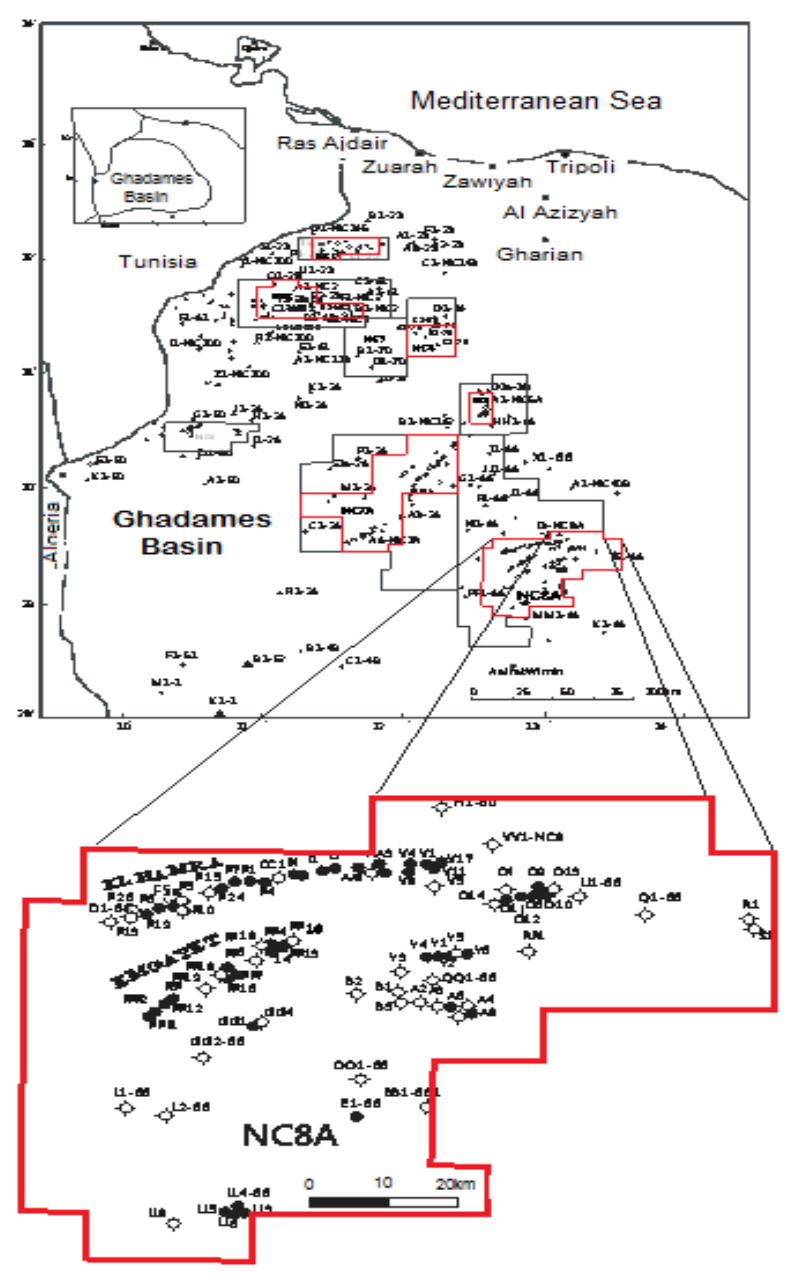

Figure1. Location map of the study area "concession NC8A", Ghadames (Hamada) Basin, NW Libya

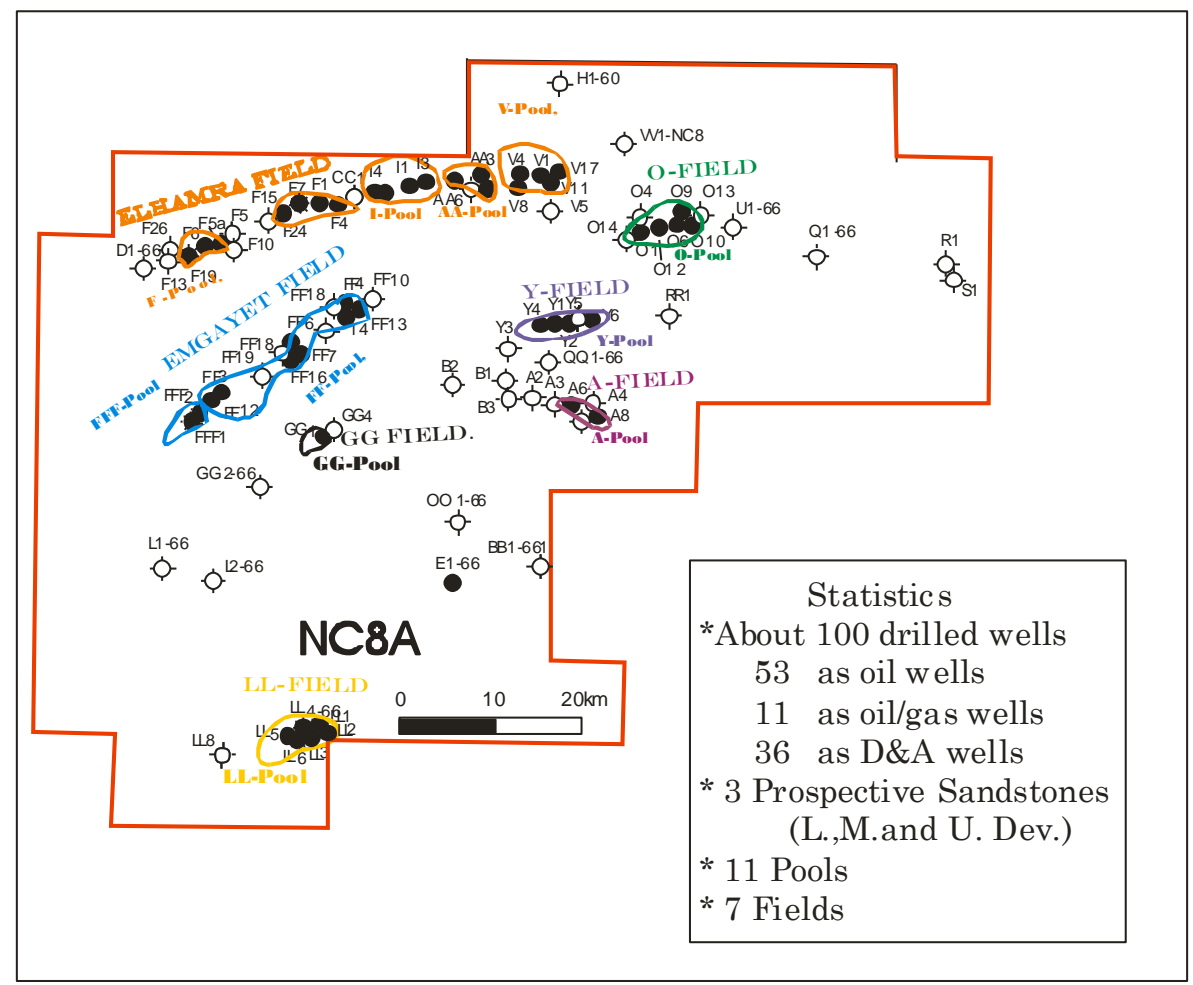

Figure2. Location map of major Fields and Pools in the Concession NC8A, Ghadames (Hamada) Basin, NW Libya 
Re-evaluation of Discovered Devonian Hydrocarbon Pools in Concession NC8A, Ghadames (Hamada) Basin, NW Libya: Volumetric Techniques Based on Deterministic Method

\section{GeOlogical BACKground}

Structurally, as inferred from studied depth-structure maps on top of some mapable horizons in the vicinity of GG-structure (Figs.3-5), where the structural style is characterized by isolated anticlinal structures bounded by reverse step faults trending NE-SW (Fig.6) especially in the vicinity of Emgayet Field (FF and FFF structures) and GG Field (GG-structure) area, of different thraw (15-40ft) to the south. These faults are inferred to be generally parallel to the margins of the Devonian paleobasins, where the origin of these faults appears to be associated with older rocks in the basin and are thus considered to be the effect of re-activation of older structures at Mesozoic or later age.
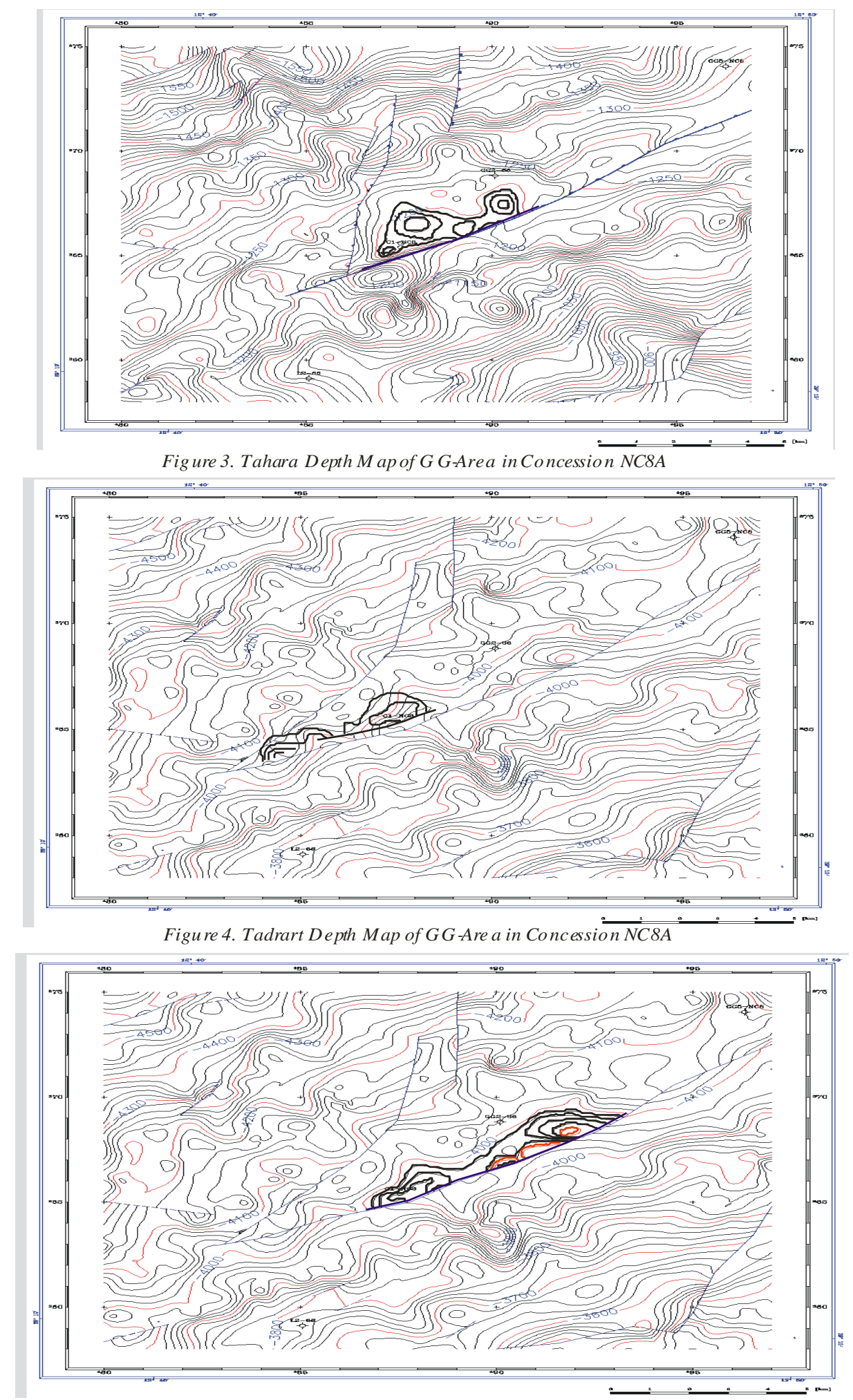

Figure 5. Memouniat Depth Map of GG-A rea in Concession NC 8A 


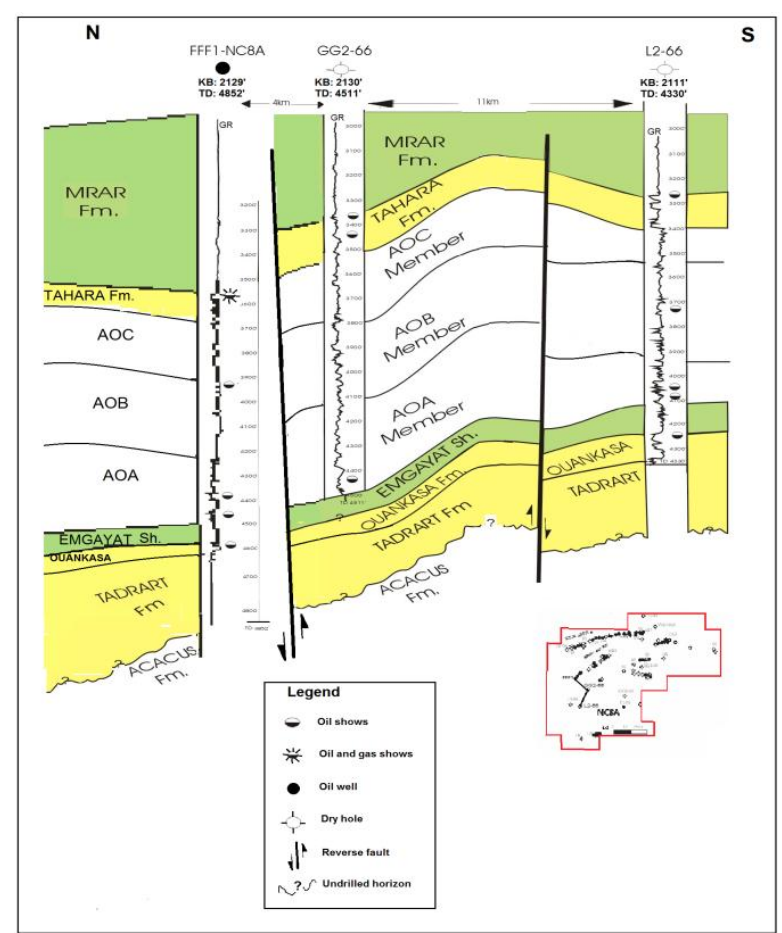

Figure6. Structural cross section between, L structure, GG structure and FFF structure in Concession NC8A, Ghadames Basin, NW Libya, showing reverse step faults trending NE-SW, with 15-40ft of thraw to the south,.

Stratigraphically, in Concession NC8A the stratigraphic sequence is characterized by Paleozoic clastic sediments as it is shown by the deep type-well LL1-66 (Fig.7), hydrocarbon-bearing horizons are also indicated. According to the best stratigraphic facies distribution of the possible prospective formations in NC8A area, and integrated core study of selected wells in the study area, the sandstone reservoirs of Ounkasa are largely fluvial in nature changing from fine-grained, highly crystalline channels to the south to more medium-grained, porous top bar facies sandstones to the north [2]. The vertical to lateral relationship of the possible clean sandstones on Tahara, Aouinat Ouenine A units and Ouankasa (Devonian sandstones) (Fig.8) can be seen as stacked channel system to the south leading to a prograded coast to deltaic sediments to eventually prodeltaic marine basinal shales to the north $[2]$.

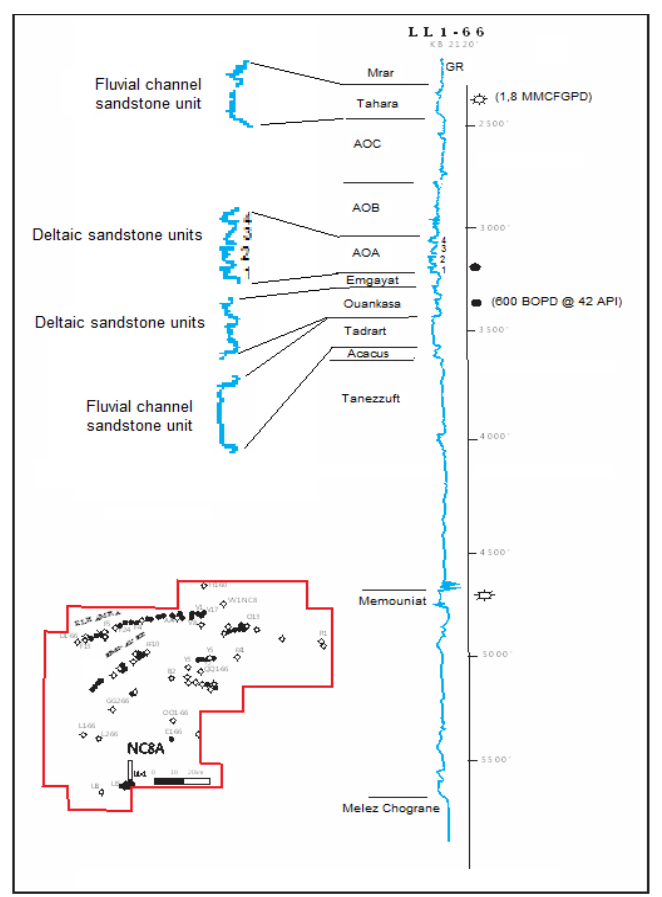

Figure7. Stratigraphic type well (LL1-66) in Concession NC8A, Ghadames Basin, NW Libya (after [2]). 


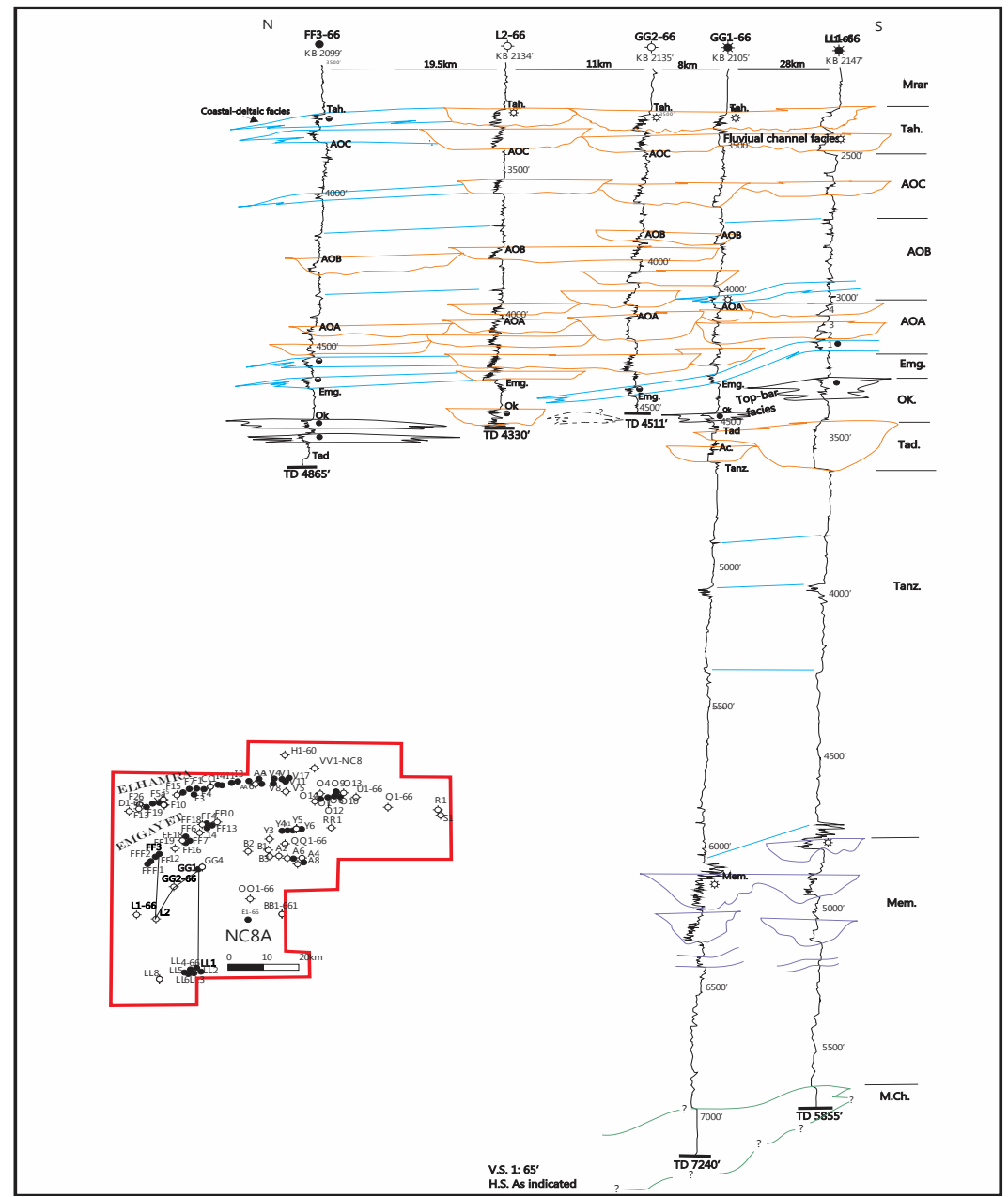

Figure8. $S-N$ stratigraphic cross section showing vertical and lateral facies distribution of Devonian Formations, in Concession NC8A, Ghadames Basin, NW Libya (after [2]).

\section{MeThodology}

An Excel spreadsheet (in database format) of discovered oil and gas resources in Concession NC8A was developed with identifiers to allow retrieval of information by reservoir characterization and producing horizon.

The present study is an independent assessments by the author for in-place and recoverable oil and gas resources and field size distribution of the studied Devonian pools in Concession NC8A.

Volumetric techniques based on deterministic method are used to indirectly estimate hydrocarbons in place (OOIP and OGIP) from estimates of area, thickness, porosity, water saturation, and hydrocarbon fluid properties, as recommended and presented in the volumetric estimation article [3], where the equations for oil are:

$$
\operatorname{OOIP}(\mathrm{STB})=\text { Rock Volume } * 7758 * \emptyset *(1-\mathrm{Sw}) * 1 / \mathrm{Bo}
$$

Recoverable Oil $=$ OOIP $*$ Recovery Factor

Where: Rock Volume (acre feet) $=\mathrm{A} * \mathrm{~h}, \mathrm{~A}=$ Drainage area (acres), $\mathrm{h}=$ Net pay thickness (feet), $7758=$ API Bbl per acre-feet (converts acre-feet to stock tank barrels), $\varnothing=$ Porosity, fraction of rock volume available to store fluids, $\mathrm{Sw}=$ Volume fraction of porosity filled with interstitial water, $\mathrm{Bo}=$ Formation volume factor (Reservoir Bbl/STB), 1/Bo = Shrinkage (STB/reservoir Bbl). To calculate recoverable oil volumes the OOIP must be multiplied by the

Recovery Factor (fraction).

The equations for gas are:

OGIP $(\mathrm{MMCF})=$ Rock Volume $* 43560 * \emptyset *(1-\mathrm{Sw}) *($ Exp.F $)$ 
Re-evaluation of Discovered Devonian Hydrocarbon Pools in Concession NC8A, Ghadames (Hamada) Basin, NW Libya: Volumetric Techniques Based on Deterministic Method

Recoverable Gas $=$ OGIP $*$ Recovery Factor

Where: Rock Volume (acre feet $)=\mathrm{A} * \mathrm{~h}, \mathrm{~A}=$ Drainage area in acres $(1$ acre $=43560$ sq. $\mathrm{ft})$, $\mathrm{h}=$ Net pay thickness in feet, $\varnothing=$ Porosity, fraction of rock volume available to store fluids,

$\mathrm{Sw}=$ Volume fraction of porosity filled with interstitial water, Exp.F= Expansion factor for gas To calculate recoverable gas volumes, the OGIP is multiplied by a recovery factor.

This deterministic method is also known as the "geologist's method" [3] as it is based on cores, analysis of wireline logs, and geological maps. Knowledge of the depositional environment, the structural complexities, the trapping mechanism is also required to accurately estimate the volume of subsurface rock that may contains hydrocarbons. The majority of reserves in Libya are estimated using this method.

\section{RESERVOIR ROCKS}

The main reservoirs in Concession NC8A are the Tahara Sandstones, Aouinat Ouenine Sandstones, and the Ouankasa Sandstones [4]. The Tahara Sandstones are characterized by parallel to crosslaminated of mainly medium grained, well sorted and in general coarsening-upward sands of coastaldeltaic origin (Fig.8), with fair to good porosity (appr. 14\%-16\%), and of effective pay thickness about 30-40ft. Oil shows in these sandstones have been encountered in wells FF3-66, GG2-66, and FFF1-NC8A (Figs 6 and 8).

The Aouinat Ouenine Sandstones can be divided into four units from base to top (AOA1, AOA2, AOA3, and AOA4) (Fig.7) [2] across the Ghadames Basin regionally and the NC8A particularly, where AOA1 and AOA2 units distribution are much confined to be recovered in the concession NC8A. These sandstone reservoirs are characterized by bioturbated silty shale at the base to parallel to cross-laminated medium grained sandstones of possible coastal-deltaic origin with average porosity of $15 \%$ at top. Oil stained samples were encountered from the wells GG2-66, FF9-66, FF15-NC8A, FF18-NC8A and FF10-NC8A (Figs 6-8).

The Ouankasa Sandstones consist of sublitharenite, fine to medium grained with fair sorting and good intergarnular porosity [2]. The porosity ranges from $14 \%$ to $16 \%$ with average $15 \%$. The average permeability ranges from $300 \mathrm{md}$ to $1500 \mathrm{md}$. Hydrocarbon potential from this reservoir is highly expected as inferred from some recovered oil shows in FF and FFF structures of Emgayet Field (Figs 6 and 8$)$.

\section{DisCovered Hydrocarbon POOLS}

A list of all discovered oil and gas fields, with discovered oil and gas reserves and pertinent identifier fields has been compiled in Excel data sheet, with an effective date of January $1^{\text {st }}, 2015$. The listings of discovered pool sizes in each field are considered to be mean values of pools areal distribution, although some are deterministic or a simple estimate. A map (Fig. 9) shows distribution of the producing horizons (or sandstone reservoirs) in all studied fields in the Concession NC8A. There are a total of 7 discovered fields, 4 of which (ElHamra, Emgayet, A and LL Fields) contain both oil and gas, 3 (G, O and Y Fields) are only oil.

On the basis of production tests, test evaluation reports, detailed structure maps, and recent seismic data, the re-evaluation of these pools have been taken into account in order to better estimate the total hydrocarbon reserves in the Concession NC8A.

\section{Volumetric Techniques "Deterministic Method" for Hydrocarbons Reserve Estimation:}

Tables (1-11) are summarizing the reservoir characterization, hydrocarbons estimation for the producing horizons in each studied pool, and the discovered oil and gas potential, by fields in the Concession NC8A. Significant differences exist in oil and gas estimates for the major fields in the Concession NC8A. ElHamra Field pools hold oil in place a total of 19.5 MMSTB and gas in place a total of 1.66 BSCF, while Emgayet Field pools hold oil in place of only 1.61 MMSTB and gas in place of about 0.60 BSCF. Other fields (O, Y, A, G and LL) hold oil in place of about 16.62 MMSTB and gas in place (only in A and LL Fields) of about 3.01 BSCF. Total oil in place "from all Devonian sandstone pools in Concession NC8A " is 36.12MMSTB while total gas in place "from all Devonian sandstone pools in Concession NC8A" is 5.21 BSCF. However, the total discovered recoverable oil 
Re-evaluation of Discovered Devonian Hydrocarbon Pools in Concession NC8A, Ghadames (Hamada) Basin, NW Libya: Volumetric Techniques Based on Deterministic Method

and gas from the all studied pools in Concession NC8A are 14.25million barrels of oil and 4.12 billion cubic feet of natural gas. Recent discoveries, for which no estimate of the discovered oil and gas is available, include C1-NC8A and D1-NC8A wells which were drilled in the vicinity of Emgayet Field.

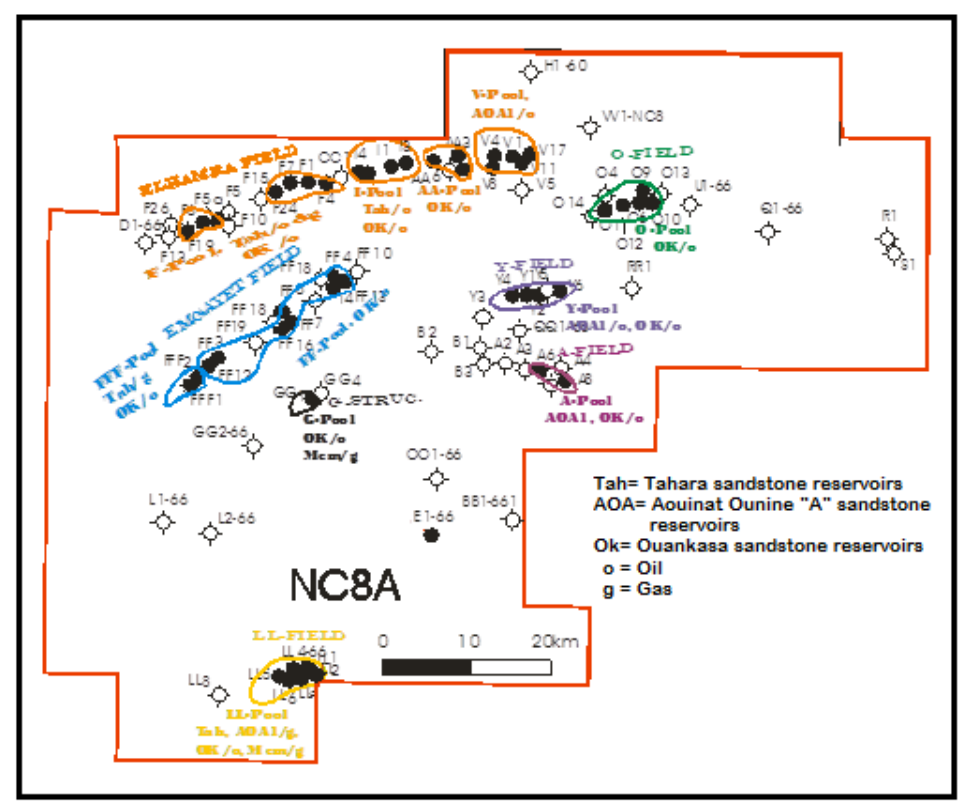

Figure9. Distribution of the producing horizons (or sandstone reservoirs) in all studied fields in the Concession $N C 8 A$

Table1. Reservoir characterization and hydrocarbons reserve estimation of F-pool sandstones, ElHamra Field, NC8A Concession, Ghadames Basin, NW Libya

\begin{tabular}{|c|c|c|}
\hline Field Name & \multicolumn{2}{|c|}{ ElHamra Field } \\
\hline Pool Name & \multicolumn{2}{|c|}{ F-Pool } \\
\hline No. of Drilled Wells & \multicolumn{2}{|c|}{13} \\
\hline No. of Producing Wells & \multicolumn{2}{|c|}{8} \\
\hline \multicolumn{3}{|c|}{ Reservoir Characterization } \\
\hline Reservoir Formation & Ouankasa & Tahara \\
\hline Age & Lower Devonian & Upper Devonian \\
\hline Seal & Emgayet Shale & Mrar Shale \\
\hline Trap & Structural & Structural \\
\hline Lithology & Sandstone & Sandstone \\
\hline Area of Closure (Acr) & 18532 & 7413 \\
\hline Average Net Pay (ft) & $20(\mathrm{o}), 15(\mathrm{~g})$ & $30(\mathrm{o}), 20(\mathrm{~g})$ \\
\hline Average Porosity (\%) & 15 & 15 \\
\hline Average Oil Saturation (\%) & 80 & 70 \\
\hline Average Gas Saturation (\%) & 80 & 60 \\
\hline Oil Gravity (API) & 30 & 32 \\
\hline Production Rate (Est.BOPD) & 500 & 700 \\
\hline Production Rate (Est.MMCFPD) & N.A & N.A \\
\hline \multicolumn{3}{|c|}{$\begin{array}{ll}\text { Hydrocarbons Reserve Estimation } \\
\end{array}$} \\
\hline OOIP (MMSTB) & 3.4 & 1.8 \\
\hline Total In Place (MMSTB) & \multicolumn{2}{|c|}{5.2} \\
\hline Rec Factor $(\%)$ & 30 & 30 \\
\hline Rec. (MMSTB) & 1.02 & 0.54 \\
\hline GIP (BSCF) & 1.2 & 0.46 \\
\hline Total In Place (BSCF) & \multicolumn{2}{|c|}{1.66} \\
\hline Rec. Factor $(\%)$ & 80 & 60 \\
\hline Rec. (BSCF) & 0.96 & 0.28 \\
\hline
\end{tabular}

$20(\mathrm{o})=$ Average oil net pay

$15(\mathrm{~g})=$ Average gas net pay

N.A = Not available 
Re-evaluation of Discovered Devonian Hydrocarbon Pools in Concession NC8A, Ghadames (Hamada) Basin, NW Libya: Volumetric Techniques Based on Deterministic Method

Table2. Reservoir characterization and hydrocarbons reserve estimation of I-pool sandstones, ElHamra Field, NC8A Concession, Ghadames Basin, NW Libya

\begin{tabular}{|c|c|c|}
\hline Field Name & \multicolumn{2}{|c|}{ ElHamra Field } \\
\hline Pool Name & \multicolumn{2}{|c|}{ I-Pool } \\
\hline No. of Drilled Wells & \multicolumn{2}{|c|}{4} \\
\hline No. of Producing Wells & \multicolumn{2}{|c|}{4} \\
\hline \multicolumn{3}{|c|}{ Reservoir Characterization } \\
\hline Reservoir Formation & Ouankasa & Tahara \\
\hline Age & Lower Devonian & Upper Devonian \\
\hline Seal & Emgayet Shale & Mrar Shale \\
\hline Trap & Structural & Structural \\
\hline Lithology & Sandstone & Sandstone \\
\hline Area of Closure (Acr) & 6177 & 12355 \\
\hline Average Net Pay (ft) & 30 & 35 \\
\hline Average Porosity (\%) & 15 & 17 \\
\hline Average Oil Saturation (\%) & 80 & 80 \\
\hline Average Gas Saturation (\%) & - & - \\
\hline Oil Gravity (API) & 27 & 30 \\
\hline Production Rate (Est.BOPD) & 700 & 540 \\
\hline Production Rate (Est.MMCFPD) & - & - \\
\hline \multicolumn{3}{|c|}{ Hydrocarbons Reserve Estimation } \\
\hline OOIP (MMSTB) & 1.7 & 4.6 \\
\hline Total In Place (MMSTB) & \multicolumn{2}{|c|}{6.3} \\
\hline Rec Factor $(\%)$ & 30 & 30 \\
\hline Rec. (MMSTB) & 0.50 & 1.4 \\
\hline GIP (BSCF) & - & - \\
\hline Total In Place (BSCF) & \multicolumn{2}{|c|}{-} \\
\hline Rec. Factor $(\%)$ & - & - \\
\hline Rec. (BSCF) & - & - \\
\hline
\end{tabular}

Table3. Reservoir characterization and hydrocarbons reserve estimation of AA-pool sandstones, ElHamra Field, NC8A Concession, Ghadames Basin, NW Libya

\begin{tabular}{|c|c|}
\hline Field Name & ElHamra Field \\
\hline Pool Name & AA-Pool \\
\hline No. of Drilled Wells & 6 \\
\hline No. of Producing Wells & 3 \\
\hline \multicolumn{2}{|c|}{$\begin{array}{l}\text { Reservoir Characterization } \\
\end{array}$} \\
\hline Reservoir Formation & Ouankasa \\
\hline Age & Lower Devonian \\
\hline Seal & Emgayet Shale \\
\hline Trap & Structural \\
\hline Lithology & Sandstone \\
\hline Area of Closure (Acr) & 6177 \\
\hline Average Net Pay (ft) & 40 \\
\hline Average Porosity $(\%)$ & 15 \\
\hline Average Oil Saturation (\%) & 70 \\
\hline Average Gas Saturation (\%) & - \\
\hline Oil Gravity (API) & 31 \\
\hline Production Rate (Est.BOPD) & 450 \\
\hline Production Rate (Est.MMCFPD) & - \\
\hline \multicolumn{2}{|c|}{ Hydrocarbons Reserve Estimation } \\
\hline OOIP (MMSTB) & 2 \\
\hline Total In Place (MMSTB) & 2 \\
\hline Rec Factor $(\%)$ & 30 \\
\hline Rec. (MMSTB) & 0.6 \\
\hline GIP $(\mathrm{BSCF})$ & - \\
\hline \multicolumn{2}{|l|}{ Total In Place (BSCF) } \\
\hline Rec. Factor $(\%)$ & - \\
\hline Rec. (BSCF) & - \\
\hline
\end{tabular}


Re-evaluation of Discovered Devonian Hydrocarbon Pools in Concession NC8A, Ghadames (Hamada) Basin, NW Libya: Volumetric Techniques Based on Deterministic Method

Table4. Reservoir characterization and hydrocarbons reserve estimation of V-pool sandstones, ElHamra Field, NC8A Concession, Ghadames Basin, NW Libya

\begin{tabular}{|c|c|}
\hline Field Name & ElHamra Field \\
\hline Pool Name & V-Pool \\
\hline No. of Drilled Wells & 17 \\
\hline No. of Producing Wells & 8 \\
\hline \multicolumn{2}{|c|}{$\begin{array}{l}\text { Reservoir Characterization } \\
\end{array}$} \\
\hline Reservoir Formation & Aouinat Ouenine "A" \\
\hline Age & Middle Devonian \\
\hline Seal & Aouinat Ouenine "B" Shale \\
\hline Trap & Structural \\
\hline Lithology & Sandstone \\
\hline Area of Closure (Acr) & 17297 \\
\hline Average Net Pay (ft) & 40 \\
\hline Average Porosity $(\%)$ & 15 \\
\hline Average Oil Saturation (\%) & 75 \\
\hline Average Gas Saturation (\%) & - \\
\hline Oil Gravity (API) & 29 \\
\hline Production Rate (Est.BOPD) & 620 \\
\hline Production Rate (Est.MMCFPD) & - \\
\hline \multicolumn{2}{|c|}{$\begin{array}{l}\text { Hydrocarbons Reserve Estimation } \\
\end{array}$} \\
\hline OOIP (MMSTB) & 6 \\
\hline Total In Place (MMSTB) & 6 \\
\hline Rec Factor $(\%)$ & 30 \\
\hline Rec. (MMSTB) & 1.8 \\
\hline GIP (BSCF) & - \\
\hline Total In Place (BSCF) & - \\
\hline Rec. Factor $(\%)$ & - \\
\hline Rec. (BSCF) & - \\
\hline
\end{tabular}

Table5. Reservoir characterization and hydrocarbons reserve estimation of FFF-pool sandstones, ElHamra Field, NC8A Concession, Ghadames Basin, NW Libya

\begin{tabular}{|c|c|c|}
\hline Field Name & \multicolumn{2}{|c|}{ Emgayet Field } \\
\hline Pool Name & \multicolumn{2}{|c|}{ FFF-Pool } \\
\hline No. of Drilled Wells & \multicolumn{2}{|c|}{2} \\
\hline No. of Producing Wells & \multicolumn{2}{|c|}{2} \\
\hline \multicolumn{3}{|c|}{ Reservoir Characterization } \\
\hline Reservoir Formation & Ouankasa & Tahara \\
\hline Age & Lower Devonian & Upper Devonian \\
\hline Seal & Emgayet Shale & Mrar Shale \\
\hline Trap & Structural & Structural \\
\hline Lithology & Sandstone & Sandstone \\
\hline Area of Closure (Acr) & 2471 & 5189 \\
\hline Average Net Pay (ft) & 35 & 30 \\
\hline Average Porosity (\%) & 15 & 14 \\
\hline Average Oil Saturation (\%) & 80 & - \\
\hline Average Gas Saturation (\%) & - & 80 \\
\hline Oil Gravity (API) & 27 & - \\
\hline Production Rate (Est.BOPD) & 620 & - \\
\hline Production Rate (Est.MMCFPD) & - & N.A \\
\hline \multicolumn{3}{|c|}{$\begin{array}{ll}\text { Hydrocarbons Reserve Estimation } \\
\end{array}$} \\
\hline OOIP (MMSTB) & & 0.81 \\
\hline Total In Place (MMSTB) & \multicolumn{2}{|c|}{0.81} \\
\hline Rec Factor $(\%)$ & 30 & - \\
\hline Rec. (MMSTB) & 0.24 & - \\
\hline GIP (BSCF) & - & 0.6 \\
\hline Total In Place (BSCF) & \multicolumn{2}{|c|}{0.6} \\
\hline Rec. Factor $(\%)$ & - & 80 \\
\hline Rec. (BSCF) & - & 0.48 \\
\hline
\end{tabular}

N.A = Not available 
Re-evaluation of Discovered Devonian Hydrocarbon Pools in Concession NC8A, Ghadames (Hamada) Basin, NW Libya: Volumetric Techniques Based on Deterministic Method

Table6. Reservoir characterization and hydrocarbons reserve estimation of FF-pool sandstones, ElHamra Field, NC8A Concession, Ghadames Basin, NW Libya

\begin{tabular}{|c|c|}
\hline Field Name & Emgayet Field \\
\hline Pool Name & FF-Pool \\
\hline No. of Drilled Wells & 19 \\
\hline No. of Producing Wells Reservoir Characterization \\
\hline Reservoir Formation & Ouankasa \\
\hline Age & Lower Devonian \\
\hline Seal & Emgayet Shale \\
\hline Trap & Structural \\
\hline Lithology & Sandstone \\
\hline Area of Closure (Acr) & 24710 \\
\hline Average Net Pay (ft) & 35 \\
\hline Average Porosity (\%) & 15 \\
\hline Average Oil Saturation (\%) & 80 \\
\hline Average Gas Saturation (\%) & - \\
\hline Oil Gravity (API) & 32 \\
\hline Production Rate (Est.BOPD) & 760 \\
\hline Production Rate (Est.MMCFPD) & - \\
\hline Hydrocarbons Reserve Estimation \\
\hline OOIP (MMSTB) & 0.80 \\
\hline Total In Place (MMSTB) & 0.80 \\
\hline Rec Factor (\%) & 30 \\
\hline Rec. (MMSTB) & 0.24 \\
\hline GIP (BSCF) & - \\
\hline Rec. Factor (\%) & - \\
\hline Rec. (BSCF) & - \\
\hline
\end{tabular}

Table7. Reservoir characterization and hydrocarbons reserve estimation of O-pool sandstones, ElHamra Field, NC8A Concession, Ghadames Basin, NW Libya

\begin{tabular}{|c|c|}
\hline Field Name & O Field \\
\hline Pool Name & O-Pool \\
\hline No. of Drilled Wells & 10 \\
\hline No. of Producing Wells & 5 \\
\hline \multicolumn{2}{|c|}{$\begin{array}{ll}\text { Reservoir Characterization } \\
\end{array}$} \\
\hline Reservoir Formation & Ouankasa \\
\hline Age & Lower Devonian \\
\hline Seal & Emgayet Shale \\
\hline Trap & Structural \\
\hline Lithology & Sandstone \\
\hline Area of Closure (Acr) & 12355 \\
\hline Average Net Pay (ft) & 30 \\
\hline Average Porosity (\%) & 16 \\
\hline Average Oil Saturation (\%) & 80 \\
\hline Average Gas Saturation (\%) & - \\
\hline Oil Gravity (API) & 27 \\
\hline Production Rate (Est.BOPD) & 480 \\
\hline Production Rate (Est.MMCFPD) & - \\
\hline \multicolumn{2}{|c|}{ Hydrocarbons Reserve Estimation } \\
\hline OOIP (MMSTB) & 3.7 \\
\hline Total In Place (MMSTB) & 3.7 \\
\hline Rec Factor $(\%)$ & 30 \\
\hline Rec. (MMSTB) & 1.1 \\
\hline GIP (BSCF) & - \\
\hline Total In Place (BSCF) & - \\
\hline Rec. Factor $(\%)$ & - \\
\hline Rec. (BSCF) & - \\
\hline
\end{tabular}


Re-evaluation of Discovered Devonian Hydrocarbon Pools in Concession NC8A, Ghadames (Hamada) Basin, NW Libya: Volumetric Techniques Based on Deterministic Method

Table8. Reservoir characterization and hydrocarbons reserve estimation of Y-pool sandstones, ElHamra Field, NC8A Concession, Ghadames Basin, NW Libya

\begin{tabular}{|c|c|c|}
\hline Field Name & \multicolumn{2}{|c|}{ Y Field } \\
\hline Pool Name & \multicolumn{2}{|c|}{ Y-Pool } \\
\hline No. of Drilled Wells & \multicolumn{2}{|c|}{6} \\
\hline No. of Producing Wells & \multicolumn{2}{|c|}{4} \\
\hline \multicolumn{3}{|c|}{ Reservoir Characterization } \\
\hline Reservoir Formation & Ouankasa & Aouinat Ouenine "A" \\
\hline Age & Lower Devonian & Middle Devonian \\
\hline Seal & Emgayet Shale & Aouinat Ouenine "B" Shale \\
\hline Trap & Structural & Structural \\
\hline Lithology & Sandstone & Sandstone \\
\hline Area of Closure (Acr) & 7413 & 3706 \\
\hline Average Net Pay (ft) & 35 & 30 \\
\hline Average Porosity $(\%)$ & 15 & 14 \\
\hline Average Oil Saturation (\%) & 80 & 70 \\
\hline Average Gas Saturation (\%) & - & - \\
\hline Oil Gravity (API) & 30 & 27 \\
\hline Production Rate (Est.BOPD) & 580 & 450 \\
\hline Production Rate (Est.MMCFPD) & - & - \\
\hline \multicolumn{3}{|c|}{$\begin{array}{l}\text { Hydrocarbons Reserve Estimation } \\
\end{array}$} \\
\hline OOIP (MMSTB) & 2.4 & 0.84 \\
\hline Total In Place (MMSTB) & \multicolumn{2}{|c|}{3.24} \\
\hline Rec Factor $(\%)$ & 30 & 30 \\
\hline Rec. (MMSTB) & 0.72 & 0.25 \\
\hline GIP $(\mathrm{BSCF})$ & - & - \\
\hline Total In Place (BSCF) & \multicolumn{2}{|c|}{-} \\
\hline Rec. Factor $(\%)$ & - & - \\
\hline Rec. (BSCF) & - & - \\
\hline
\end{tabular}

Table9. Reservoir characterization and hydrocarbons reserve estimation of A-pool sandstones, ElHamra Field, NC8A Concession, Ghadames Basin, NW Libya

\begin{tabular}{|c|c|c|}
\hline Field Name & \multicolumn{2}{|c|}{ A Field } \\
\hline Pool Name & \multicolumn{2}{|c|}{ A-Pool } \\
\hline No. of Drilled Wells & \multicolumn{2}{|c|}{4} \\
\hline No. of Producing Wells & \multicolumn{2}{|c|}{2} \\
\hline \multicolumn{3}{|c|}{ Reservoir Characterization } \\
\hline Reservoir Formation & Ouankasa & Aouinat Ouenine "A" \\
\hline Age & Lower Devonian & Middle Devonian \\
\hline Seal & Emgayet Shale & Aouinat Ouenine "B" Shale \\
\hline Trap & Structural & Structural \\
\hline Lithology & Sandstone & Sandstone \\
\hline Area of Closure (Acr) & 24710 & 1970 \\
\hline Average Net Pay $(\mathrm{ft})$ & 30 & 25 \\
\hline Average Porosity $(\%)$ & 16 & 14 \\
\hline Average Oil Saturation (\%) & 80 & - \\
\hline Average Gas Saturation (\%) & - & 70 \\
\hline Oil Gravity (API) & 30 & - \\
\hline Production Rate (Est.BOPD) & 500 & - \\
\hline Production Rate (Est.MMCFPD) & - & 7.5 \\
\hline \multicolumn{3}{|c|}{$\begin{array}{ll}\text { Hydrocarbons Reserve Estimation } \\
\end{array}$} \\
\hline OOIP (MMSTB) & 7.4 & - \\
\hline Total In Place (MMSTB) & \multicolumn{2}{|c|}{7.4} \\
\hline Rec Factor $(\%)$ & 30 & - \\
\hline Rec. (MMSTB) & 2.2 & - \\
\hline GIP (BSCF) & - & 0.17 \\
\hline Total In Place (BSCF) & \multicolumn{2}{|c|}{0.17} \\
\hline Rec. Factor $(\%)$ & - & 80 \\
\hline Rec. (BSCF) & - & 0.13 \\
\hline
\end{tabular}


Re-evaluation of Discovered Devonian Hydrocarbon Pools in Concession NC8A, Ghadames (Hamada) Basin, NW Libya: Volumetric Techniques Based on Deterministic Method

Table10. Reservoir characterization and hydrocarbons reserve estimation of GG-pool sandstones, ElHamra Field, NC8A Concession, Ghadames Basin, NW Libya

\begin{tabular}{|c|c|}
\hline Field Name & GG Field \\
\hline Pool Name & GG-Pool \\
\hline No. of Drilled Wells & 3 \\
\hline No. of Producing Wells & 2 \\
\hline \multicolumn{2}{|c|}{ Reservoir Characterization } \\
\hline Reservoir Formation & Ouankasa \\
\hline Age & Lower Devonian \\
\hline Seal & Emgayet Shale \\
\hline Trap & Structural \\
\hline Lithology & Sandstone \\
\hline Area of Closure (Acr) & 988 \\
\hline Average Net Pay $(\mathrm{ft})$ & 30 \\
\hline Average Porosity $(\%)$ & 16 \\
\hline Average Oil Saturation (\%) & 75 \\
\hline Average Gas Saturation (\%) & - \\
\hline Oil Gravity (API) & 30 \\
\hline Production Rate (Est.BOPD) & 630 \\
\hline Production Rate (Est.MMCFPD) & - \\
\hline \multicolumn{2}{|c|}{ Hydrocarbons Reserve Estimation } \\
\hline OOIP (MMSTB) & 0.28 \\
\hline Total In Place (MMSTB) & 0.28 \\
\hline Rec Factor $(\%)$ & 30 \\
\hline Rec. (MMSTB) & 0.08 \\
\hline GIP (BSCF) & - \\
\hline Total In Place (BSCF) & - \\
\hline Rec. Factor $(\%)$ & - \\
\hline Rec. (BSCF) & - \\
\hline
\end{tabular}

Table11. Reservoir characterization and hydrocarbons reserve estimation of LL-pool sandstones, ElHamra Field, NC8A Concession, Ghadames Basin, NW Libya

\begin{tabular}{|c|c|c|c|}
\hline Field Name & \multicolumn{3}{|c|}{ LL Field } \\
\hline Pool Name & \multicolumn{3}{|c|}{ LL-Pool } \\
\hline No. of Drilled Wells & \multicolumn{3}{|c|}{7} \\
\hline No. of Producing Wells & \multicolumn{3}{|c|}{6} \\
\hline \multicolumn{4}{|c|}{ Reservoir Characterization } \\
\hline Reservoir Formation & Tahara & Aouinat Ouenine "A" & Ouankasa \\
\hline Age & Upper Devonian & Middle Devonian & Lower Devonian \\
\hline Seal & Mrar Shale & $\begin{array}{c}\text { Aouinat Ouenine "B" } \\
\text { Shale }\end{array}$ & Emgayet Shale \\
\hline Trap & Structural & Structural & Structural \\
\hline Lithology & Sandstone & Sandstone & Sandstone \\
\hline Area of Closure (Acr) & 17297 & 8648 & 6177 \\
\hline Average Net Pay $(\mathrm{ft})$ & 30 & 25 & 35 \\
\hline Average Porosity $(\%)$ & 14 & 14 & 15 \\
\hline Average Oil Saturation (\%) & - & - & 80 \\
\hline Average Gas Saturation (\%) & 80 & 80 & - \\
\hline Oil Gravity (API) & - & - & 35 \\
\hline Production Rate (Est.BOPD) & - & - & 680 \\
\hline Production Rate (Est.MMCFPD) & 8.6 & 6.4 & - \\
\hline \multicolumn{4}{|c|}{ Hydrocarbons Reserve Estimation } \\
\hline OOIP (MMSTB) & - & - & 2 \\
\hline Total In Place (MMSTB) & \multicolumn{3}{|c|}{2} \\
\hline Rec Factor $(\%)$ & - & - & 30 \\
\hline Rec. (MMSTB) & - & - & 0.60 \\
\hline GIP (BSCF) & 2 & 0.84 & - \\
\hline Total In Place (BSCF) & \multicolumn{3}{|c|}{2.84} \\
\hline Rec. Factor $(\%)$ & 80 & 80 & - \\
\hline Rec. (BSCF) & 1.6 & 0.67 & - \\
\hline
\end{tabular}

Note: The areal closures of Tahara, Aouinat Ouenine " $A$ " and Ouankasa sandstone reservoirs were estimated relative to the nearest mapable horizon. 


\section{CONClusions}

A review of the discovered hydrocarbons (oil and gas) from Devonian pools in Concession NC8A has been done and figured out the ultimate original hydrocarbons in place are, 36.12 billion barrels of oil and 5.21 billion cubic feet of natural gas. This represents 53\% of the oil contributed from ElHamra Field (F, I AA and V structures), while a least percentage of only $4.5 \%$ is contributed from Emgayet Field (FFF and FF structures). Other Fields; GG, LL, Y, O and A are contributed 0.8\%, 5.5\%, 9\%, $10 \%$ and $20.5 \%$ respectively. The discovered gas in place was estimated to reveal various percentages; 54\% is contributed from LL-Field, 30\% from F-structure of ElHamra Field, 6\% from FFF-structure of Emgayet Field and 3\% is contributed from A-Field. The remaining recoverable oil and gas are 14.25 million barrels of oil and 4.12 billion cubic feet of natural gas, 39.5\%and $79 \%$ respectively of the total Concession NC8A.

\section{ACKNOWLEDGEMENTS}

I would like to express my sincere thanks and appreciation to the Department of Earth Sciences, Faculty of Science at University of Benghazi for their encouragement to publish this paper. I am also thankful to Arabian Gulf Oil Company (AGOCO)-Benghazi, for providing the data-base for this study. Thanks also extended to the anonymous reviewers for their fruitful suggested comments. Special thanks and gratitude go to my family for their patient and support to finish this paper.

\section{REFERENCES}

[1] Teknica, (1997), Exploitation Evaluation Study, ElHamra Field, Emgayet Field, GG-Structures, LL Structures, Concession NC8A, Teknica reports, Technical Data Library (TDL), Arabian Gulf Oil Company (AGOCO), Benghazi-Libya.

[2] Elfigih,O. B. 2009, Petroleum Distribution and Exploration Results from some Reservoirs in the Hamada Basin, Nw Libya. First Symposium on the Geological Resources in the Tethys Realm, Cairo University, March 2009, P. 33-52.

[3] Dean, L. 2008, Reservoir Engineering For Geologists, Part 3: Volumetric Estimation. Canadian Society of Petroleum Geologists Reservoir, V. 34, No. 11, P. 20-23.

[4] Elfigih, O. B. 2007, Re-evaluation of Discovered Hydrocarbon Pools in Concession NC7A, Hamada Basin, Internal Company Report (May-2007), Exploration Division, AGOCO, Benghazi-Libya, 11p.

\section{AUTHORS' BIOGRAPHY}

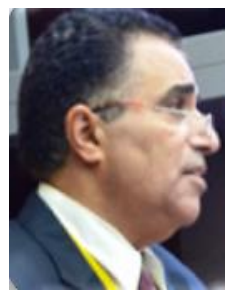

Dr. Omar B. Elfigih, has been in the oil industry since 1985 till 2009 with the Arabian Gulf Oil Company (AGOCO) Benghazi-Libya, he has focused on multidisciplinary integration of geological data used in well-site operations and prospect generation in various concessions in the Ghadames Basin, NW Libya, and as technical geological supervisor for the exploration group of the Hamada Basin. He holds MSc. and $\mathrm{PhD}$ degrees in petroleum geology from Memorial University of Newfoundland-Canada.

Dr. Elfigih, worked for Bp company- Libyan branch as consultant in petroleum geology in some of their concessions in NW Libya. He joined the Department of Earth Sciences at University of Benghazi since 2009 and taught many courses; stratigraphy, sedimentology, structure geology, petroleum geology, basin analysis, and applied sedimentology for both undergraduate and postgraduate programs. Supervising many MSc. theses in the field of petroleum geology. Head of scientific affairs at the University of Technical Research for Engineering Sciences (UTRES).He was the head of Earth Sciences Department, Faculty of Science, University of Benghazi from Oct. 2014 to Oct. 2016. He is now an associate professor at the Department of Earth Sciences-University of Benghazi.

Citation: Omar B. Elfigih, (2017). Re-evaluation of Discovered Devonian Hydrocarbon Pools in Concession NC8A, Ghadames (Hamada) Basin, NW Libya: Volumetric Techniques Based on Deterministic Method, International Journal of Petroleum and Petrochemical Engineering (IJPPE), 3(4), pp.65-77, DOI: http://dx.doi.org/10.20431/2454-7980.0304006

Copyright: (C) 2017 Omar B. Elfigih. This is an open-access article distributed under the terms of the Creative Commons Attribution License, which permits unrestricted use, distribution, and reproduction in any medium, provided the original author and source are credited 